2292

日本機械学会論文集 $(\mathrm{A}$ 編)

論文 No. 93-0447

59 巻 566 号 $(1993-10)$

\title{
研削加エされた炭化けい素セラミックスの高温酸化*
}

\author{
兼 松 涉*1，三宅 卓 志*2 \\ 森川 久*3, 久保勝司*1
}

\section{High Temperature Oxidation of Ground Silicon Carbide Ceramics}

\author{
Wataru KANEMATSU, Takushi MIYAKE, \\ Hisashi MORIKAWA and Katsushi KUBO
}

\begin{abstract}
The relationship between oxygen penetration depth into ground silicon carbide ceramics during oxidation and the extent of the affected layer has been studied. The penetration depth was determined by measuring oxygen profile using the SIMS technique. The depths of ground ceramics oxidized at 1200 and $1500^{\circ} \mathrm{C}$ were expressed as the function of the maximum grain depth of cut $g$ which is related to the depth of median crack in grinding. The penetration depth was smaller than the crack size. The increase in oxidation time hardly affected the penetration depth at $1200^{\circ} \mathrm{C}$. It is suggested that the oxide film prevents further oxygen penetration and that the oxygen penetration has little effect on the strength at elevated temperatures.
\end{abstract}

Key Words : Ceramics, Brittle Fracture, Corrosion, Affected Layer, Oxidation, SIMS (Secondary Ion Mass Spectrometer)

\section{1. 緒言}

セラミックスは $1000^{\circ} \mathrm{C}$ 以上の高温においても，そ の高い強度を維持するとともに優れた耐食性を有する ため高温構造部材としての利用が期待されている。し かしながら，セラミックスと言えども高温酸化雲囲気 下においては酸化による損傷が問題となり, 部材の強 度，寿命に大きな影響を及ぼすことが知られている。 例えばガスタービン部材などでは燃焼ガスに接する部 材表面に酸化ピットが形成され，表面がはく離したり， 強度特性が劣化することが問題となっている(1).

これまでセラミックスの高温酸化に関しては, 焼結 体の粒界特性や微構造などの材料特性と酸化增量や組 織の変化などの酸化特性との関係を中心に論じられて きた(2).さらに最近, 酸化後の破壊挙動についても検 討されはじめた (3).しかし酸化特性は，材料特性だけ ではなく, 酸素分圧 ${ }^{(4)}$, 温度, 湿度(5)など雰囲気の影 響を受けるものであり，部材のそれを論じる場合には，

\footnotetext{
* 原稿受付 平成 5 年 3 月 30 日.

*1 正員, 工業技術院名古屋工業技術試験所（ 462 名古屋市北 区平手町 1-1).

*2 正員，名古屋市工業研究所( 4456 名古屋市熱田区六番 3-441).

*3 工業技術院名古屋工業技術試験所.
}

雲囲気に接触する部材表面の状態すなわち，表面に分 布するき裂，表面粗さなどの影響を考慮すべきものと 考えられる。

言うまでもなく部材表面の状態は加工の影響を受け る. 著者らはセラミック部材の代表的な加工方法であ る研削加工とその加工損傷の度合について検討を加え てきた。その中で，研削加工面にはき裂が残留し，その き裂寸法が部材強度を支配することを明らかにし た ${ }^{(6)}$.さらに, 高温酸化雲囲気中では加工き裂の形状・ 寸法が変化し強度劣化を引き起こす可能性のあること を示した ${ }^{(7)}$ 、本報では，前報において高温強度を測定 した試験片を対象に, 二次イオン質量分析器(SIMS) を用いて酸素侵入深さを調へ，加工損傷の度合と酸化 との関係について検討するとともに，新たに 100 時間 までの長時間の酸化試験を行い, 酸化時間と, 即時破 壊強度および酸素侵入深さとの関係についても調へ る.

\section{2. 実 験 方 法}

供試材はボロン, カーボンを焼結助材として添加し た常圧焼結炭化けい素セラミックスである. 試験片寸 法, 表 1 に示す研削加工条件は前報(6) と同じである. 各作業条件の組合せにより最大砥粒切込み深さを変化 
させることで, 加工損傷の度合に違いを与えた．本材 料は $0.3 \%$ 弱の酸素を含有しているが, 粒界での酸化 物相の偏析がほとんどないので，酸素侵入深さの同定 が容易となる。

試験片の加熱は大気雲囲気中で行い, 酸化温度は $1200^{\circ} \mathrm{C}$ および $1500^{\circ} \mathrm{C}$ とした。昇温パターンは図 1 に示すように加熱時間が同一となるように $200^{\circ} \mathrm{C}$ か らの昇温速度を調節し, 酸化時間は 15 分を標準とし たが, 酸素侵入深さおよび高温強度の酸化時間依存性 を調べるため, $1200^{\circ} \mathrm{C}$ において $2,12,100$ 時間保持 した試料も準備した。

炭化けい素の酸化は一般に, 比較的高い酸素分圧の 雲囲気中では，表面にシリカ $\mathrm{SiO}_{2}$ の保護膜が形成さ れる passive 酸化であることが知られている(8). 上述 のように本材料は粒界に酸化物相がほとんどないと考 えられるので, 炭化けい素の構成元素であるシリコン $\mathrm{Si}$ に対する酸素Oの相対濃度分布を測定すれば酸素 侵入深さが推定できる，本研究では，この濃度分布の 測定にSIMS を用いることとした。

SIMS とは，数 $\mathrm{keV} \sim$ 十数 $\mathrm{keV}$ のエネルギーをも ったイオンビームを試料面に照射し，イオンが試料面 を衝撃することによって発生する二次イオン強度を測 定する表面分析法の一種である。本法は検出感度が他 の分析法に比べ高く，イオンビーム径を絞ることによ って局所的な元素分布の測定が可能である，などの特 徵を有する(9). SIMS による測定は図 2 に示すような

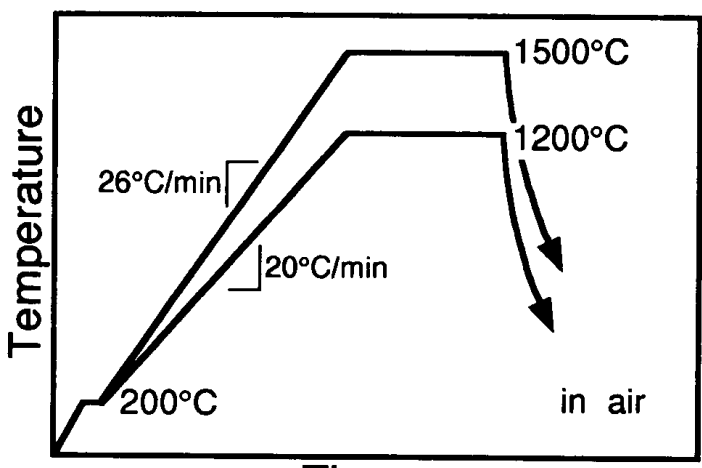

Time

図 1 昇温パターン

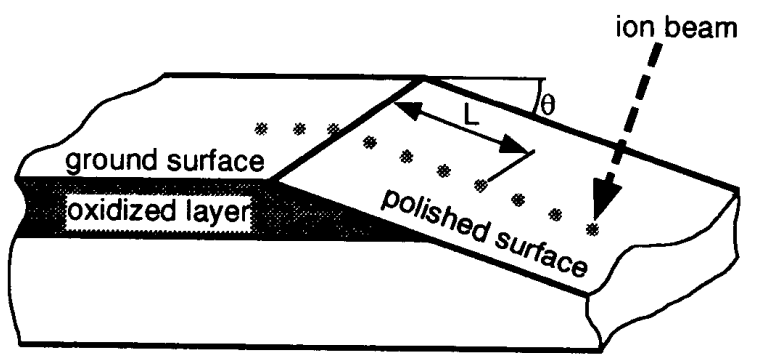

図 2 SIMS を用いた深さ方向酸素莀度分布測定の概念
方法で行った．曲げ試験片の引張応力面に対して傾斜 角 $\theta$ で斜め研磨を行った試料を用意し，研磨面上を約 $30 \mu \mathrm{m}$ 間隔でイオンビームを照射して, Si とOの二 次イオン強度を測定する。測定位置の表面からの深さ は $\theta$ と研磨面上での表面からの距離 $L$ から算出する. $\theta$ は，研磨した試料を表面粗さ測定装置を用いて測定 した結果, 1.5〜1.9 度の範囲にあった。な㧍, SIMS (Cameca 社 IMS-3 F) の設定条件は表 2 に示す。約 8 $\mathrm{keV}$ の加速電圧を加えたアルゴンイオンビームを直 径 $5 \mu \mathrm{m}$ まで校り試料電流を $50 \mathrm{nA}$ とした。二次イオ ン種は正イオンを対象とし，エネルギー幅は $60 \mathrm{eV}$, 測定時間は一点当たり 1 秒とした。

\section{3. 結 果と考察}

$3 \cdot 1$ 酸素侵入深さの同定 図 3 は高温下で酸化 した研削加工材の深さ方向の酸素濃度分布を示すもの で, 縦軸は ${ }^{30} \mathrm{Si}$ の二次イオン強度に対する ${ }^{16} \mathrm{O}$ のそれ

表 1 加工条件

\begin{tabular}{lccl}
\hline peripheral wheel speed & 1500 & $\mathrm{~m} / \mathrm{min}$ \\
work speed & $0.2 \sim 10 \mathrm{~m} / \mathrm{min}$ \\
wheel depth of cut & 8 & $\mu \mathrm{m}(200 \mathrm{grit})$ \\
& & 4 & $\mu \mathrm{m}(400 \mathrm{grit})$ \\
cross feed & & 5 & $\mathrm{~mm} /$ pass \\
spark out & & 0 & \\
\hline
\end{tabular}

表 2 SIMS 測定条件

\begin{tabular}{cc}
\hline $\begin{array}{c}\text { Primary ion } \\
\text { species }\end{array}$ & Ar \\
energy & $8.0 \sim 8.1 \mathrm{keV}$ \\
current & $50 \mathrm{nA}$ \\
spot size & $5 \mu \mathrm{m \phi}$ \\
Secondary ion & \\
polarity & positive \\
count time & $1 \mathrm{sec}$ \\
energy width & $60 \mathrm{eV}$ \\
\hline
\end{tabular}

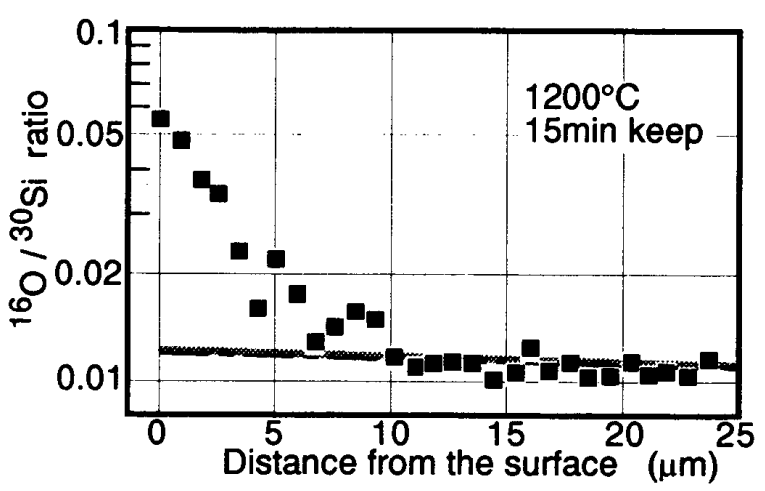

図 3 研削加工材の高温酸化による深さ方向の酸素濃度分 布 (最大砥粒切込み深さ $g=1.39 \mathrm{~mm}$ ) 
の比(以下，イオン強度比と呼ぶ)を片対数グラフ表示 している.イオン強度比が表面に近いほど高くなって いるのは酸素の侵入によるものと考え, イオン強度比 がバックグラウンドレベルに滅少するまでの深さを加 工損傷による酸素侵入深さ $d_{\mathrm{ox}}$ とした。その判定には 次のような基準を用いた。イオン強度比の変化が小さ くなる領域を直線近似し, 測定値と近似値との差の標 準偏差(図 3 のハッチング部分の幅)を求める。測定值 と近似值との差が, この標準偏差よりも大きくなる深 さを $d_{\mathrm{ox}}$ とした。

なお, 長時間の応力負荷では酸化の度合が応力の影 響を受けることが報告されている(10)が, 本研究は即 時破壊強度を測定したものであるため負荷時間が短く その影響は小さいと考えられる，実際，同一試験片の 最大応力が加わる部分と無負荷部分との $d_{\mathrm{ox}}$ を比較し た結果，両者にはほとんど差が見られなかった。ここ では, 酸素侵入深さの負荷応力による影響はほとんど 無視できるものとした.

$3 \cdot 2$ 研削加工条件による酸素侵入深さの変化 本研究で用いた研削加工材表面には加工によるき裂が 残留していることを確認している(6). 研削加工材表面 のき裂としては，砥粒進行方向に平行に進展するメデ イアンき裂と，これと垂直方向に進展するラディアル

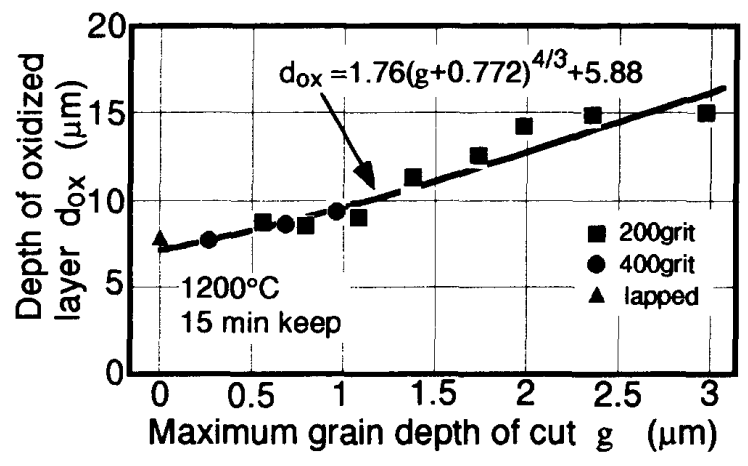

図 4 最大砥粒切込み深さによる酸素侵入深さの表示

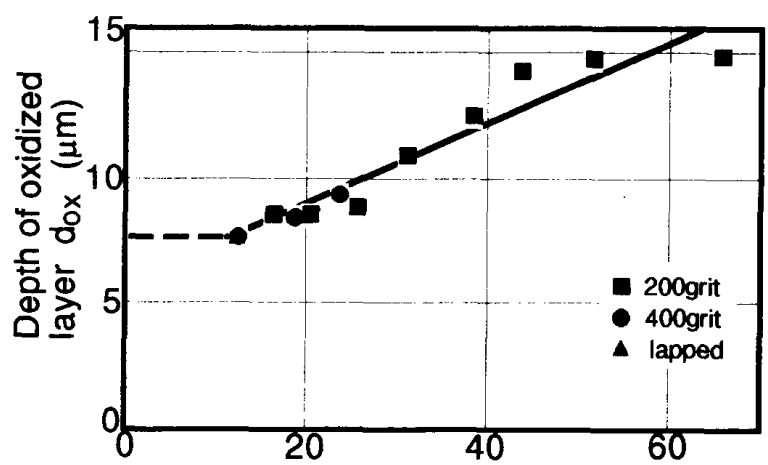

Depth of crack (calculated) $(\mu \mathrm{m})$

図 5 研削加工によるメディアンき裂深さと酸素侵入深さ との比較
き裂があるが(11), 部材強度への影響が大きいのは，き 裂樑さの大きい前者である。

前報で示したように研削加工によって発生するメデ イアンき裂が圧子押し込みの場合と同様の力学モデ ル(12) で説明できるとすると, き裂深さcは最大砥粒 切込み深さ $g$ の指数関数で表され, 本研究における供 試材については式（1）で示すような実験式で与えられ ている，著者らは前報(6)において，この実験式がき裂 深さの実測值の傾向を比較的よく表すことを確認して いる.

$$
c=11.9(g+0.772)^{4 / 3}
$$

ここで, $c, g$ の単位は $\mu \mathrm{m}$ である. $g$ は砥石切込み, テ ーブル速度などの研削作業条件および砥石粒度，砥粒 含有率などの砥石仕様の関数として与えられるので， 加工条件がわかれば，き裂梁さの見積もりができるこ とになる。ここでは，酸素侵入深さとメディアンき裂 深さとの関係について考察することとした。

酸素侵入深さがき裂哚さに比例すると仮定すると式 (1)より, 次式が得られる。

$$
d_{\mathrm{ox}}=a(g+0.772)^{4 / 3}+b
$$

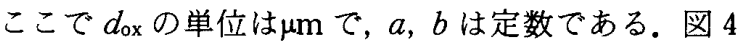
は $3 \cdot 1$ 節の方法で求めた酸素侵入深さ $d_{0 \mathrm{x}}$ を $g$ で表示 したもので, 両者の関係を式 (2)の形で近似すると, 図中の実線で示す次式が得られる。

$$
d_{\mathrm{ox}}=1.76(g+0.772)^{4 / 3}+5.88
$$

式 ( 3 )を用いることにより加工条件から酸素侵入深さ を見積もることができる。

図 5 は, 式(1)で与えられるメディアンき裂深さ $c$ と図 4 の酸素侵入深さとの関係を比較したものであ

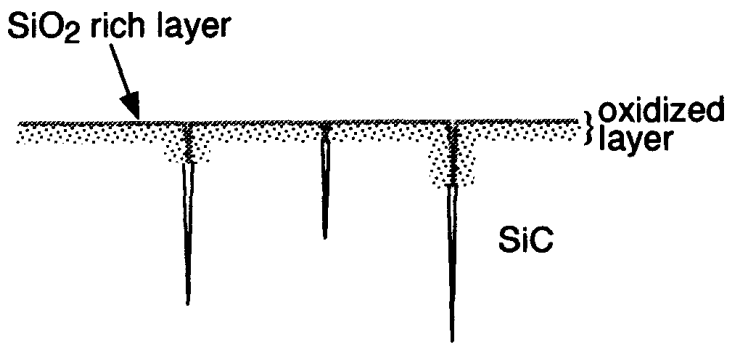

(a)

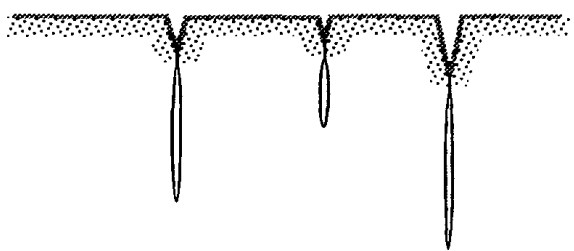

(b)

図 6 研削加工材の高温酸化モデル 
る. 図 5 は, 酸素侵入深さはき裂深さの計算值に比べ かなり小さく，き裂先端まで酸化層が形成されていな いことを示唆している．このような現象を説明するモ デルとして以下の二つが考えられる. (1)図 6 (a)に示 すように，き裂開口部において比較的短時間に $\mathrm{SiO}_{2}$ リッチの膜が形成され新たな酸素の侵入が困難となる (2)同図 (b)に示すように研削加工によって発生した開 口き裂が, 圧縮残留応力や摩擦熱などの原因で砥粒通 過後に閉じられる(13) ため, 酸素の侵入が困難となる. しかし，以下のような理由から前者のモデルが妥当と 考えられる。

著者らは先に加工損傷を有するホットプレス窒化け い素に対し，室温大気中において，一定応力速度で負 荷をかける動疲労試験を行い, その破壊強度は応力速 度が小さくなるにつれて低下することを示した ${ }^{(14)}$.こ れは大気中の水分による粒界ガラス相の応力腐食(15) によるものと推定された。すなわち，応力負荷中は，き 裂は開口状態にあり水分子がき裂先端まで到達し得る ことを示している。本研究における供試材は上述のよ うに粒界にガラス相をほとんどもたないが，これによ ってき裂発生形態に大きな差は生じないと考えられ る。したがって，本研究のように応力を負荷された条

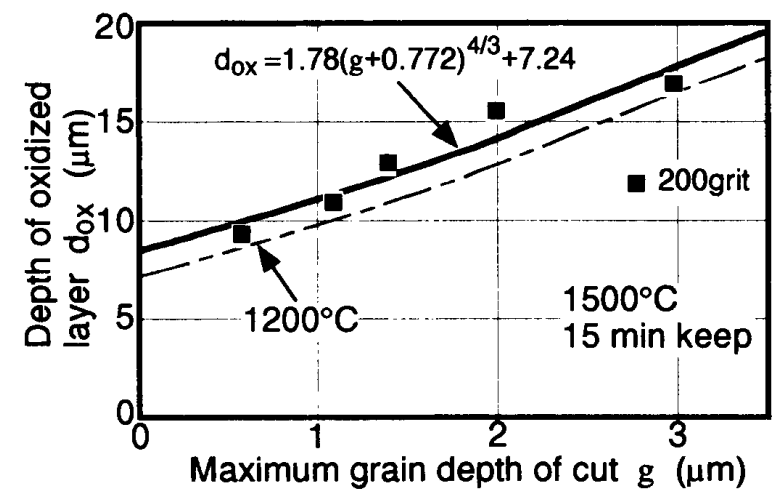

図 7 酸化温度による酸素侵入深さの変化

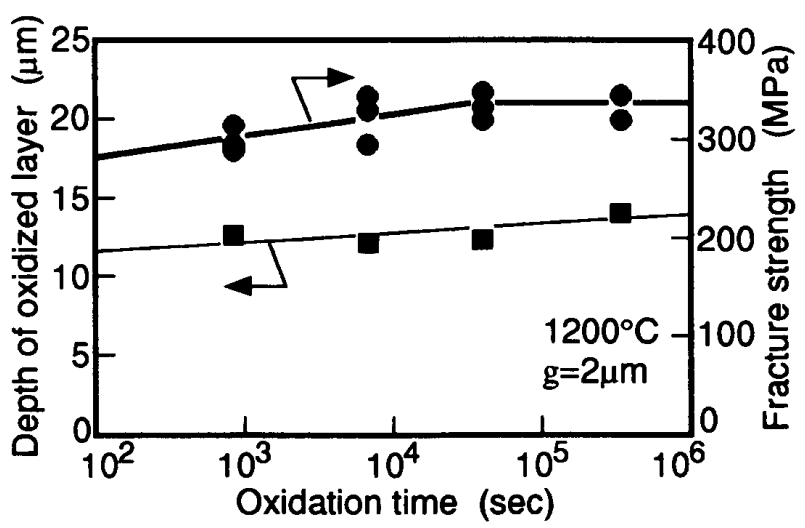

図 8 酸素侵入深さおよび即時破壊強度に及ほす酸化時間 の影響
件下では図 6 (b)で想定している閉口き裂の酸化にお いても, 同図 (a) と同様の結果が得られると推定され る.

$3 \cdot 3$ 酸化温度および酸化時間による酸素俊入深さ および高温即時破壞強度の変化 図 7 は $1500^{\circ} \mathrm{C}$ に おける $d_{0 x}$ の $g$ に対する変化を示す．図中の一点鎖線 で示す $1200^{\circ} \mathrm{C}$ における近似直線と比較すると, 温度 上昇による $d_{0 x}$ の変化は比較的小さく $g$ に対する変 化は $1200^{\circ} \mathrm{C}$ の場合を平行移動したような形となっ た。このような現象の原因としては以下のようなメカ ニズムが推定される．3・2節で述べたように試験片表 面には短時間で $\mathrm{SiO}_{2}$ リッチの膜ができ, 大気と母材 との接触が困難となる。 しかし, 絶対温度の指数関数 で表される搪散係数は温度上昇により大きくなるので $1500^{\circ} \mathrm{C}$ では酸素が拡散により膜の中を通って母材中 に侵入すると考えられる。

一般に，セラミックスのような硬脆材料の強度は最 弱リンク説に支配されるため, き裂先端まで酸素が侵 入していない限り強度への酸化の影響は小さいと考え られる. $3 \cdot 2$ 節で述べたように $d_{0 x}$ は $c$ に比べ小さく, しかも図 8 に示すように酸化時間の増加に対してほと んど変化は見られなかった。したがって，酸化温度 $1200^{\circ} \mathrm{C}$ においては高温強度に対する酸化の影響は小 さいと考えられる．また図中の太い実線に示すように， 酸化後の高温強度は酸化時間の増加に伴ってわずかに 上昇する傾向も見られるが，100 時間酸化した後でも その上昇率はわずかであった。
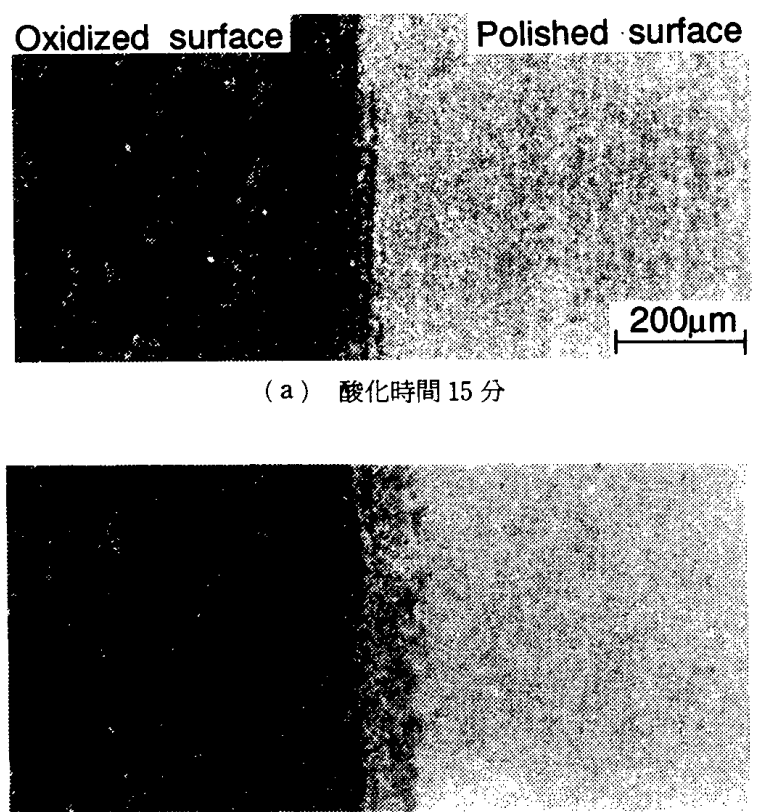

（b）酸化時間 100 時間

図 9 長時間酸化による表面層の変化 


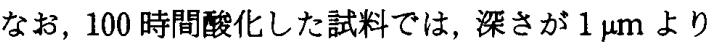
も浅い測定点でイオン強度比が 1 を越える值を示し た。このことは，表面層がほとんどシリカに変化して いることを示唆している．図 9 は斜め研磨面を光学顕 微鏡を用い, 偏向フィルタを通して観察した結果であ る. 同図 (a)の酸化時間 15 分の場合に比べ, 同図 (b) の酸化時間 100 時間の場合は, 表面直下に母材とは異 なる組織が形成されていることがわかる，斜め研磨面 の傾斜角から，この部分の厚さは $1 \mu \mathrm{m}$ 程度と換算さ れることから，上記の組織がシリカ層に相当するもの と考えられる。このことから, 酸化温度が $1200^{\circ} \mathrm{C} の$ 場合酸化時間の增加によって酸素侵入深さはほとんど 変化しないが, 表面近傍の酸化が進み, 母材である炭 化けい素のほとんどがシリカに変わるものと推定され た、シリカは高温では粘性流動を起こすことが知られ ており ${ }^{(16)}$, 炭化けい素との界面強度は母材強度に比べ 弱いと考えられる。したがって高速の燃焼ガスが吹き 付けるような実際の使用条件下では，部材表面におい て酸化膜の形成，その脱落が繰返されることによって 損傷がひどくなることが予想される。

\section{4. 結}

ボロン，カーボンを焼結助材とする常圧焼結炭化け い素セラミックスを供試材として，研削加工されたセ ラミックスの, 高温大気中での酸化の度合と加工損傷 との関係について検討した。得られた結果を以下に要 約する。

（1）二次イオン質量分析器を用いて酸素侵入深さ $d_{\mathrm{ox}}$ を同定した。

（2） $d_{0 x}$ は研削加工によるメディアンき裂深さ $c$ と最大砥粒切込み深さ $g$ との関係を用いることによ り, $g$ の指数関数として与えられる.

（3） $d_{0 x}$ はcに比べかなり小さい. その原因とし ては比較的短時間に表面にシリカリッチの膜が形成さ
れ，酸素の侵入が困難となるためと考えられた。

（4） $1500^{\circ} \mathrm{C}$ における $d_{\mathrm{ox}}$ は $1200^{\circ} \mathrm{C}$ の場合に比 べ若干増加する。これは，温度上昇による拡散係数の 増加によってシリカリッチの膜を通しての母材中への 酸素の拡散が顕著になるためと推定された。

（5） $1200^{\circ} \mathrm{C}$ においては， $d_{0 x}$ は $c$ に比べ小さく， しかも酸化時間の増加に対してほとんど変化しなかっ たことから，強度を支配するき裂の先端までは酸素が 侵入しておらず強度に対する酸化の影幚は小さいと考 えられた。また，酸化時間の増加によって表面近傍の 酸化が進み，母材である炭化けい素のほとんどがシリ 力に変化する。

\section{文献}

（1）阿部・久松・石川・宮田・飯島・大島, 日本ガスタービン 学会誌, 14-54 (1986), 20

（2）例えば, 前田・中村・東，日本セラミックス協会学術論文 誌, 96-7 (1988), 795.

（3）河本・近藤, 機論, 58-556, A (1992), 2321.

(4) Narushima, T., Goto, T. and Hirai, T., J. Am. Ceram. Soc., 72-8 (1989), 1386.

(5) Narushima, T., Goto, T., Iguchi, Y. and Hirai, T., J. Am. Ceram. Soc., 73-12 (1990), 3580.

（6）兼松・山内・大司・伊藤・久保, 日本セラミックス協会学 術論文誌, 100-6 (1992), 775.

（7）兼松・伊藤・久保，日本セラミックス協会学術論文誌，1016 (1993), 698.

（8）阿部・川合・菅野・鈴木, エンジニアリングセラミックス, (1984），161，技報堂出版.

（9）染野・安盛, 表面分析, (1976)，21, 講談社サイエンティフ イク.

(10) Costello, J. A. and Tressler, R. E., Ceramics Int., 11-2 (1985), 39.

（11）張・戸倉・吉川, 精密工学会誌, 54-8 (1988), 1537.

(12) Lawn, B. R. and Fuller, E. R., J. Mater. Sci., 10 (1975), 2016.

（13）中村・平井 - 久保, 害業協会誌, 94-7 (1986), 683

（14）兼松・酒井・山内・伊藤・久保, 日本セラミックス協会学 術論文誌, 98-11 (1990), 1287.

(15) 文献 ( 8 )の 141 ページ.

（16）小松・ほか 4 名共訳, セラミックス材料科学入門, (1981), 728, 内田老鶴團。 